\title{
Transferability of microsatellite markers in Syagrus coronata (Mart.) Becc. (Arecaceae), an iconic palm tree from the Brazilian semiarid region
}

\author{
R.R. Simplicio ${ }^{1}$, D.G. Pereira ${ }^{2}$ and A.M. Waldschmidt ${ }^{1}$ \\ ${ }^{1}$ Departamento de Ciências Biológicas, \\ Universidade Estadual do Sudoeste da Bahia, Jequié, BA, Brasil \\ ${ }^{2}$ Departamento de Química e Exatas, \\ Universidade Estadual do Sudoeste da Bahia, Jequié, BA, Brasil \\ Corresponding author: R.R. Simplicio \\ E-mail: renatasimpliciouesb@gmail.com
}

Genet. Mol. Res. 16 (2): gmr16029699

Received March 12, 2017

Accepted May 5, 2017

Published June 29, 2017

DOI http://dx.doi.org/10.4238/gmr16029699

Copyright $(C 2017$ The Authors. This is an open-access article distributed under the terms of the Creative Commons Attribution ShareAlike (CC BY-SA) 4.0 License.

\begin{abstract}
The licuri palm Syagrus coronata plays a key role in the ecology and economy of Brazilian semiarid region. Nonetheless, genetic data about populations of this species are absent even though the intensive and uncontrolled exploitation since colonial periods has threatened the sustainability and viability of licuri populations. Therefore, we attempted to test the efficacy of transferability of microsatellite loci isolated from three palm tree species to $S$. coronata to analyze the population of this species throughout their range. A set of 19 heterologous microsatellite loci was tested in three native populations of $S$. coronata from the State of Bahia, northeastern Brazil, which amplified using distinct annealing temperatures $\left(50^{\circ}-60^{\circ} \mathrm{C}\right)$. Based on the 10 most polymorphic loci, the selected populations exhibited a mean number of alleles per locus of 9.8, and high genetic
\end{abstract}


diversity values since the expected heterozygosity ranged from 0.573 to 0.754 , while the observed heterozygosity varied from 0.785 to 1.000 . In conclusion, the tested loci are transferrable and highly efficient to population studies in $S$. coronata, thus minimizing the lack of speciesspecific loci to the genetic monitoring of licuri populations.

Key words: Arecaceae; Caatinga; Conservation genetics; SSR

\section{INTRODUCTION}

Several palm tree species have been widely exploited because of their useful resource to human communities; this is the case of the licuri palm Syagrus coronata (Mart.) Becc. (Arecacea), a species of biological and social-economic relevance in the semiarid region of Brazil, being widespread from the northern portion of the State of Minas Gerais, central and eastern parts of Bahia, Sergipe, Alagoas to southern Pernambuco (Drumond, 2007).

Because of their high energetic fruits and high resistance to drought periods, the licuri palm has been historically harvested as a food source. Therefore, the large-scale exploitation of this palm since colonial periods has reduced or extinguished populations along their original range. However, genetic studies in populations of the licuri palm are virtually unavailable, even though their spatial distribution in the semiarid landscape is well known and $S$. coronata has been a target of biofuel production (Ramalho, 2008).

In this sense, the simple sequence repeats (SSR) or microsatellites stand out as one of the most useful molecular markers to assess gene flow, genetic diversity, and population structure in vegetal species (Xiao et al., 2014). These codominant markers comprise highly polymorphic in tandem repeats ( 1 to 6 nucleotides) widespread throughout the genome of eukaryotes, particularly in non-coding regions. In the face of the fast-evolving environmental and economic crisis, efficient tools for the diagnosis of vulnerability status of species that play a key role in ecosystems, such as the licuri palm, should be developed. Since speciesspecific microsatellite markers in $S$. coronata are absent, the transferability of heterologous loci represents a viable alternative to infer gene flow among populations and the selection of priority areas for conserving genetic diversity and evolutionary potential of vulnerable species. Usually, the success of amplification using heterologous primers depends on previously reported data about related species (e.g., congeneric taxa) because of the occurrence of homologous microsatellite regions (Cota et al., 2012).

Therefore, the goal of the present study was to test the efficiency of transferability of SSR primers developed for three palm species - Cocos nucifera L. (Arecaceae), Bactris gasipaes Kunth (Arecaceae), and Euterpe edulis Mart. (Arecaceae) - for the amplification of microsatellite loci in S. coronata (Mart.) Becc. (Arecaceae). This result can be useful to further population genetic studies in the licuri palm, thus contributing to the genetic conservation and management of this species.

\section{MATERIAL AND METHODS}

\section{Sampling}

Samples of S. coronata were obtained from three municipalities in the State of Bahia,

Genetics and Molecular Research 16 (2): gmr16029699 
northeastern Brazil: Serrinha, Cocos, and Jequié. Each population was composed of 10 specimens, totaling 30 samples. A minimum distance of $10 \mathrm{~m}$ among individuals was adopted to collect samples within each locality. The inflorescences were deposited in the Herbarium at Universidade Estadual do Sudoeste da Bahia (HUESB).

\section{DNA extraction}

About $100 \mathrm{~g}$ tissue from young leaves of $S$. coronata was used for the DNA extraction, following the protocol developed by Arruda (2014). The amount and integrity of extracted DNA were verified by electrophoresis on $0.8 \%$ agarose gel, stained with GelRed ${ }^{\circledR}$ and photodocumented under UV using the L-pix ${ }^{\circledR}$ system.

\section{Amplification and analysis of SSR loci}

A set of 19 microsatellite primers previously developed for $C$. nucifera (Perera et al., 1999; Rivera et al., 1999), B. gasipaes (Billotte et al., 2004; Rodrigues et al., 2004), and E. edulis (Gaiotto et al., 2001) was tested in DNA samples of $S$. coronata. The amplification of SSR loci via PCR (polymerase chain reaction) was carried out according to Peters et al. (1998).

Each reaction comprised $1 \mu \mathrm{L} 10 \mathrm{X}$ buffer (BioTools), $0.2 \mu \mathrm{L}$ of each primer at 20 $\mu \mathrm{M}, 0.3 \mu \mathrm{L} \mathrm{MgCl}_{2}$ at $50 \mathrm{mM}, 0.4 \mu \mathrm{L}$ dNTP at $2.5 \mathrm{mM}, 5 \mathrm{U} 0.1 \mu \mathrm{L}$ Taq polymerase, $10 \mathrm{ng}$ template DNA, and ultrapure water to a final volume of $10 \mu \mathrm{L}$. The PCR was performed using a thermocycler (Applied Biosystems) with the following program: an initial denaturation step at $94^{\circ} \mathrm{C}$ for $3 \mathrm{~min}$, followed by 40 cycles of denaturation at $92^{\circ} \mathrm{C}$ for $30 \mathrm{~s}$, annealing according to the tested temperature gradient $\left(50^{\circ}, 52^{\circ}, 54^{\circ}, 56^{\circ}, 58^{\circ}\right.$, and $\left.60^{\circ} \mathrm{C}\right)$ for $1 \mathrm{~min}$ and extension at $72^{\circ} \mathrm{C}$ for $30 \mathrm{~s}$, plus a final extension step at $72^{\circ} \mathrm{C}$ for $5 \mathrm{~min}$.

The amplification products were genotyped using a MegaBace-1000 (GE Healthcare, Buckinghamshire) automated sequencer. The size of fragments was established based on genotyping peaks after comparison with the ET550R size marker in the MegaBace Fragment Profiler v. 2.2 software (GE Healthcare). A preliminary analysis was carried out to identify and correct putative genotype errors using Micro-Checker v. 2.2.3 (Peakall and Smouse, 2012).

The 10 most polymorphic SSR loci amplified from the licuri palm were evaluated using the GenAlEx software (Peakall and Smouse, 2012) by estimating the expected $\left(H_{\mathrm{E}}\right)$ and observed $\left(H_{\mathrm{O}}\right)$ heterozygosity values, the number of alleles per locus $\left(N_{\mathrm{A}}\right)$, and deviations from the Hardy-Weinberg equilibrium (HWE) for each primer per sampled population.

\section{RESULTS}

The 19 tested loci were free of null alleles and properly amplified at distinct annealing temperatures, ranging from $50^{\circ}$ to $60^{\circ} \mathrm{C}$ (Table 1). Among them, 10 markers were the most polymorphic ones and isolated from $C$. nucifera and B. gasipaes.

The genetic analysis of these 10 polymorphic loci in $S$. coronata revealed 5 to $12 N_{\mathrm{A}}$ and high levels of genetic diversity $\left(H_{\mathrm{E}}=0.573-0.754\right)$. Similarly, the $H_{\mathrm{O}}$ values varied from 0.785 to 1.000 , being higher than the $H_{\mathrm{E}}$ (Table 2). Significant HWE deviation was observed for the loci CNZ50 and CNZ23 in the population from Cocos municipality $(\mathrm{P}<0.001)$, as well as for CNZ23, Bg02-09, and mBgCIR066 in samples from Jequié and CNZ50 in the population from Serrinha $(\mathrm{P}<0.005)$.

Genetics and Molecular Research 16 (2): gmr16029699 
Table 1. Sequences of tested heterologous loci in Syagrus coronata, with their respective fragment size in bp and best annealing temperature (Ta).

\begin{tabular}{|c|c|c|c|}
\hline Primers & Sequence $\left(5^{\prime}-3^{\prime}\right)$ & Fragment size & $\mathrm{Ta}\left({ }^{\circ} \mathrm{C}\right)$ \\
\hline \multirow[t]{2}{*}{$\mathrm{Bg} 02-09$} & F: CGCAGCAGCAGCAATAAATA & \multirow[t]{2}{*}{$170-174$} & \multirow[t]{2}{*}{60} \\
\hline & R: TCCAGCAACTTTCAGTCGAG & & \\
\hline \multirow[t]{2}{*}{$\mathrm{Bg} 02-10$} & F: ATTGGGTCCAGATCCTCTTT & \multirow[t]{2}{*}{$150-176$} & \multirow[t]{2}{*}{52} \\
\hline & R: GTGGCACACATGGGGTTC & & \\
\hline \multirow{2}{*}{ CNZ03 } & F: CATCTTTCATCATTTAGCTCT & \multirow{2}{*}{$132-140$} & \multirow[t]{2}{*}{60} \\
\hline & R: AAACCAAAAGCAAGGAGAAGT & & \\
\hline \multirow[t]{2}{*}{ CNZ04 } & F: CCTATTGCACCTAAGCAATTA & \multirow[t]{2}{*}{$128-158$} & \multirow[t]{2}{*}{56} \\
\hline & R: TGATTTTCGAAGAGAGGTC & & \\
\hline \multirow[t]{2}{*}{ CNZ10 } & F: CCTATTGCACCTAAGCAATTA & \multirow[t]{2}{*}{$129-169$} & \multirow[t]{2}{*}{50} \\
\hline & R: ATGATTTTCGAAGAGAGGTC & & \\
\hline \multirow[t]{2}{*}{ CNZ13 } & F: TATGCTATTCACTCATTTTTCG & \multirow[t]{2}{*}{$138-178$} & \multirow[t]{2}{*}{60} \\
\hline & R: ACTCTGTTTCACGATCAAAAA & & \\
\hline \multirow[t]{2}{*}{ CNZ23 } & F: ATCAAAACATGACACCGTAAC & \multirow[t]{2}{*}{$133-163$} & \multirow[t]{2}{*}{58} \\
\hline & R: CTGATAGATGACAAGGTGTGG & & \\
\hline \multirow[t]{2}{*}{ CNZ26 } & F: CTAGGCTCCCCATGTGTTTTT & \multirow[t]{2}{*}{$216-240$} & \multirow[t]{2}{*}{58} \\
\hline & R: CACTGCTGTTGTACACCTCCA & & \\
\hline \multirow[t]{2}{*}{ CNZ44 } & F: CATCAGTTCCACTCTCATTTC & \multirow[t]{2}{*}{$139-151$} & \multirow[t]{2}{*}{60} \\
\hline & R: CAACAAAAGACATAGGTGGTC & & \\
\hline \multirow[t]{2}{*}{ CNZ50 } & F: TCGACTAAGTGTTGTCCATTC & $114-120$ & 54 \\
\hline & R: ATCCATCCAGGATCCCAATAT & & \\
\hline CNZ51 & F: CTTTAGGGAAAAAGGACTGAG & $138-150$ & 60 \\
\hline & R: ATCCATGAGCTGAGCTTGAAC & & \\
\hline CNZ57 & F: AGTGACAGCTCAAAGCAGTAT & $99-105$ & 50 \\
\hline & R: GTGGAGTACACAACCTATGGA & & \\
\hline $\mathrm{CAC} 2$ & F: AGCTTTTTCATTGCTGGAAT & $229-243$ & 50 \\
\hline & R: CCCCTCCAATACATTTTTCC & & \\
\hline mBgCIR053 & F: TTCAGTTAAGACCACCTATCA & $148-176$ & 56 \\
\hline & R: ACGAAGAAATCGAACCATAC & & \\
\hline mBgCIR058 & F: TTTGATACCCCAGAGAGA & $243-289$ & 60 \\
\hline & R: AGCGAGAAACACGAATAC & & \\
\hline mBgCIR066 & F: GCATGTTGCATTGACTA & $253-257$ & 54 \\
\hline & R: GAATCCTGGTTCAGATACT & & \\
\hline mBgCIR091 & F: CAAGAACAGGCTCAGTCTA & $200-212$ & 60 \\
\hline & R: TGCAATCAACCCAAGAT & & \\
\hline EE41 & F: CCTTGCAGTTTATGGCTACG & $114-122$ & 52 \\
\hline & R: CCATTGAGAGGGAATGAGGT & & \\
\hline EE54 & F: CATGTATCTAAGGAACAAGG & $113-115$ & 60 \\
\hline & R: CTGTGCTCTCTCATTCTCA & & \\
\hline
\end{tabular}

Table 2. Genetic diversity parameters (number of alleles per loci - $N_{\mathrm{A}}$; expected heterozygosity - $H_{\mathrm{E}}$; and observed heterozygosity $-H_{\mathrm{O}}$ ) in Syagrus coronata based on 10 transferrable heterologous loci.

\begin{tabular}{l|c|c|c}
\hline Locus & $N_{\mathrm{A}}$ & $H_{\mathrm{E}}$ & $H_{\mathrm{O}}$ \\
\hline $\mathrm{mBgCI053}$ & 12 & 0.741 & 0.926 \\
\hline $\mathrm{mBgCI066}$ & 10 & 0.697 & 0.911 \\
\hline Bg02-10 & 11 & 0.754 & 0.932 \\
\hline Bg02-09 & 12 & 0.752 & 0.833 \\
\hline CNZ03 & 9 & 0.748 & 0.785 \\
\hline CNZ23 & 12 & 0.753 & 0.969 \\
\hline CNZ44 & 8 & 0.704 & 1.000 \\
\hline CNZ50 & 10 & 0.721 & 0.923 \\
\hline CNZ57 & 5 & 0.573 & 0.836 \\
\hline Mean & 9 & 0.722 & 0.989 \\
\hline
\end{tabular}

\section{DISCUSSION}

Because of the high species diversity and the costs of developing specific microsatellite markers, the transferability of heterologous primers is a suitable alternative to studies of population genetics in biodiversity hotspots (Barbará et al., 2007). This approach has been

Genetics and Molecular Research 16 (2): gmr16029699 
successfully used in both vegetal and animal groups, such as pollinators (Viana et al., 2011) and dispersers.

Indeed, the efficient transferability of the 19 tested SSR primers to amplify microsatellite loci in $S$. coronata corroborates the applicability of heterologous primers to genetic studies in palm trees, thus allowing refined population analysis in licuri palms. Among the heterologous primers amplified in S. coronata, 11 were originally developed for C. nucifera (Perera et al., 1999; Rivera et al., 1999). This result could be related to the close phylogenetic relationship between the genera Syagrus and Cocos within the subtribe Attaleinae, as revealed by the analysis of seven genes encoding specific transcription factors in plants (Meerow et al., 2009). Closely related species and transferability of SSR loci can be higher than $60 \%$ (Barbará et al., 2007).

Moreover, the 10 selected microsatellite loci showed high values of $H_{\mathrm{E}}$ (Table 2), indicating high genetic diversity that should be important to the maintenance and adaptability of natural populations. Nonetheless, some loci exhibited increased $H_{\mathrm{O}}$ values (near or equal to $1.0)$, such as CNZ23 $\left(H_{\mathrm{O}}=0.969\right)$ with significant deviation from HWE $(\mathrm{P}<0.005)$. Thus, in spite of the high values of genetic diversity, the deviation from HWE indicates the influence of distinct evolutionary forces, including the putative role of genetic drift by population fragmentation (Frakham et al., 2008), what should be further analyzed.

Similarly, the transferability of 31 SSR markers described for Passiflora edulis Sims and Passiflora alata Dryander (Passifloraceae) allowed evaluating the genetic diversity in Passiflora setacea D.C. with views to conservation and genetic improvement (Pereira et al., 2015). These authors also reported high values of $H_{\mathrm{O}}$ with the significant deviation $(\mathrm{P}<0.01)$ from HWE for all loci. Within Citrus, Cristofani-Yaly et al. (2011) obtained 100\% efficiency in cross-species amplification using 24 SSR loci. These reports reinforce that genetic studies in species of great economic and ecological importance can benefit from the application of heterologous microsatellite primers.

Even though $S$. coronata is a key element to the biodiversity of caatinga, a threatened biome typical of the Brazilian semiarid region, little is known about its population structure. In fact, most genetic studies are focused on other palm species such as Elaeis guineenses Jacq. (Arecaceae) (Austin et al., 2015) and Syagrus romanzoffiana (Cham.) Glassman (Arecaceae) (Giombini et al., 2013). Therefore, the results from the present study provided a large number of microsatellite loci suitable for population studies in $S$. coronata. Based on the transferability of heterologous SSR primers, the levels of gene flow and genetic structure can be established in licuri palm populations, which are useful to the conservation and in situ or ex situ management of this iconic species from caatinga.

\section{Conflicts of interest}

The authors declare no conflict of interest.

\section{ACKNOWLEDGMENTS}

The authors are grateful to "Programa de Formação de Recursos Humanos - Petrobras" (\#PRH-PB 211) and "Fundação de Amparo à Pesquisa da Bahia" (FAPESB) for the financial support and the scholarship on behalf of R.R. Simplicio, and to the Herbarium at Universidade Estadual do Sudoeste da Bahia (HUESB) for the assistance in species identification.

Genetics and Molecular Research 16 (2): gmr16029699 


\section{REFERENCES}

Arruda SR (2014). Diversidade e estrutura genética de Mimosa tenuiflora (Wild.) Poir.: Importante recurso florestal do semiárido brasileiro. Master's thesis, UESB, Jequié.

Austin KG, Kasibhatla PS, Urban DL, Stolle F, et al. (2015). Reconciling oil palm expansion and climate change mitigation in Kalimantan, Indonesia. PLoS One 10: e0127963. https://doi.org/10.1371/journal.pone.0127963

Barbará T, Palma-Silva C, Paggi GM, Bered F, et al. (2007). Cross-species transfer of nuclear microsatellite markers: potential and limitations. Mol. Ecol. 16: 3759-3767. https://doi.org/10.1111/j.1365-294X.2007.03439.x

Billotte N, Couvreur T, Marseillac N, Brottier P, et al. (2004). A new set of microsatellite markers for the peach palm (Bactris gasipaes Kunth); characterization and across-taxa utility within the tribe Cocoeae. Mol. Ecol. Notes 4: 580582. https://doi.org/10.1111/j.1471-8286.2004.00741.x

Cota LG, Moreira PA, Menezes EV, Gomes AS, et al. (2012). Transferability and characterization of simple sequence repeat markers from Anacardium occidentale to A. humile (Anacardiaceae). Genet. Mol. Res. 11: 4609-4616. https:// doi.org/10.4238/2012.October.17.7

Cristofani-Yaly M, Novelli VM, Bastianel M and Machado MA (2011). Transferability and Level of Heterozygosity of microsatellite Markers in Citrus Species. Plant Mol. Biol. Report. 29: 418-423. https://doi.org/10.1007/s11105-010$\underline{0241-\mathrm{x}}$

Drumond MA (2007). Licuri Syagrus coronata (Mart.) Becc. Petrolina. Embrapa Sémi-Árido, Pernambuco.

Frakham R, Ballou JD and Briscoe DA (2008). Fundamentos da Genética da Conservação. Sociedade Brasileira de Genética, São Paulo.

Gaiotto FA, Brondani RPV and Grattapaglia D (2001). Microsatellite markers for Heart of Palm - Euterpe edulis and E. oleracea Mart (Arecaceae). Mol. Ecol. Notes 1: 86-88. https://doi.org/10.1046/j.1471-8278.2001.00036.x

Giombini MI, Tosto DS and Bravo SP (2013). Characterization of 20 microsatellites in the Neotropical palm Syagrus romanzoffiana (Arecaceae) identified by cross-amplification from across genera. Mol. Ecol. Notes 12: 1196-1197.

Meerow AW, Noblick L, Borrone JW, Couvreur TLP, et al. (2009). Phylogenetic analysis of seven WRKY genes across the palm subtribe Attaleinae (Arecaceae) [corrected] identifies Syagrus as sister group of the coconut. PLoS One 4: e7353. https://doi.org/10.1371/journal.pone.0007353

Peakall R and Smouse PE (2012). GenAlEx 6.5: genetic analysis in Excel. Population genetic software for teaching and research--an update. Bioinformatics 28: 2537-2539. https://doi.org/10.1093/bioinformatics/bts460

Pereira DA, Gaiotto FA, Corrêa RX and Oliveira AC (2015). Heterologous primer transferability and access to microsatellite loci polymorphism in "somnus" passion fruit tree (Passiflora setacea DC). Biotemas 3: 51-56.

Perera L, Russell JR, Provan J and Powell W (1999). Identification and characterization of microsatellite loci in coconut (Cocos nucifera L.) and the analysis of coconut populations in Sri Lanka. Mol. Ecol. 8: 344-346.

Peters JM, Queller DC, Fonseca VL and Strassmann JE (1998). Microsatellite loci for stringless bees. Mol. Ecol. 7: 784787.

Ramalho CI (2008). Estrutura da vegetação e distribuição espacial do licuri Syagrus coronata (Mart) Becc. em dois municípios do Centro Norte da Bahia, Brasil. Universidade Federal de Pernambuco, Areia.

Rivera R, Edwards KJ, Barker JHA, Arnold GM, et al. (1999). Isolation and characterization of polymorphic microsatellites in Cocos nucifera L. Genome 42: 668-675. https://doi.org/10.1139/g98-170

Rodrigues DP, Vinson C, Ciampi AY, Farias IP, et al. (2004). Novel microsatellite markers for Bactris gasipaes (Palmae). Mol. Ecol. Notes 4: 575-576. https://doi.org/10.1111/j.1471-8286.2004.00739.x

Viana MVC, Miranda EA, de Francisco AK, Carvalho CAL, et al. (2011). Transferability of microsatellite primers developed for stingless bees to four other species of the genus Melipona. Genet. Mol. Res. 10: 3942-3947. https://doi. org/10.4238/2011.November.22.11

Xiao Y, Zhou L, Xia W, Mason AS, et al. (2014). Exploiting transcriptome data for the development and characterization of gene-based SSR markers related to cold tolerance in oil palm (Elaeis guineensis). BMC Plant Biol. 14: 384-396. https://doi.org/10.1186/s12870-014-0384-2

Genetics and Molecular Research 16 (2): gmr16029699 